\title{
Hydrogen production from algal biomass via steam gasification
}

\author{
Gozde Duman ${ }^{a}$, Md. Azhar Uddin ${ }^{\mathrm{b}}$, Jale Yanik ${ }^{\mathrm{a}, *}$ \\ ${ }^{a}$ Faculty of Science, Department of Chemistry, Izmir Institute of Technology, 35430 Urla, Izmir, Turkey \\ ${ }^{\mathrm{b}}$ Department of Environmental Chemistry and Materials, Okayama University, 3-1-1 Tsushima Naka, Okayama 700-8530, Japan
}

\section{H I G H L I G H T S}

- Steam gasification may be a promising way to produce hydrogen from algae.

- Use of catalysts enhanced both tar degradation and hydrogen production.

- Amount of hydrogen production was dependent on the algae species and the type of catalysts used.

\section{A R T I C L E I N F O}

\section{Article history:}

Received 16 February 2014

Received in revised form 22 April 2014

Accepted 25 April 2014

Available online 5 May 2014

\section{Keywords:}

Algae

Steam gasification

Hydrogen

Iron catalyst

\begin{abstract}
A B S T R A C T
Algal biomasses were tested as feedstock for steam gasification in a dual-bed microreactor in a two-stage process. Gasification experiments were carried out in absence and presence of catalyst. The catalysts used were $10 \% \mathrm{Fe}_{2} \mathrm{O}_{3}-90 \% \mathrm{CeO}_{2}$ and red mud (activated and natural forms). Effects of catalysts on tar formation and gasification efficiencies were comparatively investigated. It was observed that the characteristic of algae gasification was dependent on its components and the catalysts used. The main role of the catalyst was reforming of the tar derived from algae pyrolysis, besides enhancing water gas shift reaction. The tar reduction levels were in the range of $80-100 \%$ for seaweeds and of $53-70 \%$ for microalgae. $\mathrm{Fe}_{2} \mathrm{O}_{3}-\mathrm{CeO}_{2}$ was found to be the most effective catalyst. The maximum hydrogen yields obtained were $1036 \mathrm{cc} / \mathrm{g}$ algae for Fucus serratus, $937 \mathrm{cc} / \mathrm{g}$ algae for Laminaria digitata and $413 \mathrm{cc} / \mathrm{g}$ algae for Nannochloropsis oculata.
\end{abstract}

(ㄷ) 2014 Elsevier Ltd. All rights reserved.

\section{Introduction}

Algae are a very promising feedstock for the following reasons: a high growth rate (up to $20 \mathrm{~g}$ dry algae per $\mathrm{m}^{2}$ per day), widespread availability, high efficiency in $\mathrm{CO}_{2}$ capture and solar energy conversion, and no competition with agricultural food. Seaweeds which are considered as macroalgae have numerous advantages over other terrestrial biomass. Transport of nutrient and water is not needed for seaweeds. This saves energy, and many types of seaweed have a higher mass productivity than terrestrial biomass (Wi et al., 2009). They are used as human foods, cosmetics, fertilisers and as a source of chemicals for medicine and industry (Ross et al., 2008).

Currently, algae are gaining increasing interest as a feedstock for production of gas and liquid fuels. Numerous techniques have been tested for the production of biofuel from algal biomass including solvent extraction for biodiesel, supercritical water gasification and anaerobic digestion, for bio-gas, and pyrolysis,

\footnotetext{
* Corresponding author. Address: Faculty of Science, Department of Chemistry, Ege University, 35100 Bornova, Turkey. Tel./fax: +90 2323888264.

E-mail address: jale.yanik@ege.edu.tr (J. Yanik).
}

for bio-oil. In the conversion of algal biomass to biofuels, the technological drawbacks are also present, namely the high water and salt contents. Extensive work has been done on the production of biodiesel from microalgae having high productivity of biomass and oil (Ferreira et al., 2013). Other potential biofuels can be derived from the algal biomass by thermochemical and biochemical routes. Anaerobic digestion, as biochemical route, is appropriate for wet algal biomass to produce $\mathrm{CH}_{4}$. But, the $\mathrm{CH}_{4}$ production strongly depends on the algae composition, $\mathrm{pH}$, temperature, hydraulic and solid retention time and loading rate (Singh and Olsen, 2011). Recently, pyrolysis has been widely studied as an alternative to obtain bio-oil from algae. Some of these studies were reviewed by Marcilla et al. (2013). The major drawback of pyrolysis is the need of upgrading of bio-oil. One of the alternative processes for algal biomass containing large amounts of water up to $90 \%$ is the hydrothermal liquefaction and gasification. There are reviews concerning production of bio-oil and $\mathrm{CH}_{4} / \mathrm{H}_{2}$ gasification, though hydrothermal process is a useful technology for algae (Yeh et al., 2013; Ruiz et al., 2013). Main challenge in hydrothermal treatment of algae is high salt content leading to corrosion and blockage salt precipitates. 
Gasification is also alternative to produce bio-gas from algae. There are many studies of biomass gasification using different agents such as $\mathrm{CO}_{2}$, steam, air (Hanaoka et al., 2005; Garcia et al., 2001; Gil et al., 1999) Steam gasification has more advantage among the other agents (Mermoud et al., 2006). Furthermore, the good quality of the gas with a high percentage of hydrogen is obtained by steam. The main problem of steam gasification is the formation of tar which is variable mixture of condensable hydrocarbons. Reduction of tar formation can be achieved by different ways such as varying the operating conditions, adding catalysts to the feedstock, mechanical cleaning of cold gas and using secondary catalytic bed to decompose tar into gas products (Anisa et al., 2011). In the case of using secondary catalytic bed, many type of catalysts were studied (Hu et al., 2006; Florin and Harris, 2008; Kimure et al., 2006). Iron based catalysts are widely used to decompose of tar (Min et al., 2011; Uddin et al. 2008; Khelfa et al., 2009; Hurley et al., 2012; Xie et al., 2009; Tang et al., 2010; Xiwei et al., 2012). In addition they enhance water gas shift reaction $\left(\mathrm{H}_{2} \mathrm{O}+\mathrm{CO} \rightarrow \mathrm{H}_{2}+\mathrm{CO}_{2}\right)$ which produces $\mathrm{H}_{2}$. A previous study by Hurley et al. (2012) demonstrated that the iron ore (limonite) produced a higher yield of hydrogen than that of olivine in gasification of woody biomass in an air-blown fluidized-bed reactor. Khelfa et al. (2009) reported that in the presence of steam, haematite is active in the gasification and hydrogen production, is able to breakdown the tar produced during the thermal degradation of the lignocellulosic biomass. Similar results of increasing hydrogen formation by water-gas shift reaction in presence of $\mathrm{Fe}_{2} \mathrm{O}_{3}$ were also reported by Xie et al. (2009). But, the bulk iron catalysts were deactivated rapidly, so dispersed iron on a support is a more efficient catalysts (Tang et al., 2010). In most reports, the catalysts modified by loading with iron were tested for steam tar reforming and the results showed that iron modified catalysts were effective in both steam reforming reaction and water-gas shift reaction (Xiwei et al., 2012; Liu et al., 2010). On the other hand, it was suggested that $\mathrm{CeO}_{2}$ supported catalysts, e.g., $\mathrm{Pt} / \mathrm{CeO}_{2}$, is a promising catalyst for the steam reforming of biomass-based oxygenates (Güell et al., 2011). Güell et al. (2009) investigated the catalytic performance of a ceria-zirconia based catalyst for steam $/ \mathrm{CO}_{2}$ gasification and combustion of char produced during pyrolysis oil evaporation. Their study showed that a ceria-zirconia based catalyst $\mathrm{Ce}-\mathrm{Zr}-\mathrm{O}$ enhanced $\mathrm{CO}_{2}$ and steam gasification of char derived from pyrolysis oil significantly. Because of red-ox properties, the use of $\mathrm{CeO}_{2}$ as support may improve the catalytic stability of iron based catalysts for tar degradation and hydrogen production via water-gas shift reaction in steam gasification. $\mathrm{CeO}_{2}$ has also been investigated as $\mathrm{Ni}$ supports for biomass gasification (Miyazawa et al., 2006). And it was reported that $\mathrm{CeO}_{2}$ support played an important role on the decreasing of carbon deposition.

In this study, the steam gasification of three different species of algae was studied. One of them is Nannochloropsis sp., which can be considered a promising green microalga for microalgal oil production because of its high lipid content. In the present work, the gasification of Nannochloropsis sp. residue was studied for a biorefinery approach consisting in the production of a wide range of biofuels from Nannochloropsis sp. The other algae, Fucus serratus and Laminaria digitata, are seaweed having very low lipid content. A previous study showed that pyrolysis is not a suitable process for bio-oil production from them (Yanik et al., 2013). In contrast to pyrolysis, hydrothermal gasification of $F$. serratus and $L$. digitata could potentially produce a hydrogen and methane-rich gas (Schumacher et al., 2011). Herein, these seaweeds were taken for gasification study to compare the steam gasification with hydrothermal gasification.

Although, many efforts have been addressed towards producing bio oil and bio gas from algal biomass, a very few studies investigated the steam gasification of algae. Kaewpanha et al. (2014) investigated the synergy effect of steam co-gasification of a brown seaweed and land-based biomass. And they suggested that the alkali and alkaline earth metals in brown seaweed acted as the catalysts to enhance the gasification of land-based biomass in cogasification process. Furthermore, Sanchez-Silva et al. (2013) investigated the steam gasification characteristics of the Nannochloropsis gaditana microalgae char by means of TGA. They studied the effects of different operation conditions, such as particle size, initial weights, temperature, gas flow rate and water vapour concentration, on the char conversion.

The first objective of this study was to investigate the hydrogen production from seaweeds ( $F$. serratus, $L$. digitata) and a microalga (Nannochloropsis oculata) by catalytic steam gasification. The second objective of this study was to investigate the effect of catalyst on the tar degradation and hydrogen production in steam gasification. This paper will give some primary results concerning the catalytic steam gasification of algal biomass to produce hydrogen.

\section{Methods}

\subsection{Materials}

Three different algal biomasses were used as a feedstock. Elemental composition and metal analysis of algae was shown in Table 1 . The two species of seaweeds (F. serratus, L. digitata) were collected from the Bantry coast on the south-west coast of Ireland. They were washed in water and dried in oven at $60^{\circ} \mathrm{C}$. N. oculata which is a kind of microalgae was supplied in a project (FP7 Marie-Curie IAPP-Project No: 230598). After extraction of lipids in Nannochloropsis sp. with hexane, the algal residue was dried in oven at $105^{\circ} \mathrm{C}$. Algae species (F. serratus, L. digitata and N. oculata) will be denoted as $F S, L D$ and $N O$, respectively.

\subsection{Catalyst preparation and characterization}

The red mud was supplied by Seydisehir Aluminium Company, Turkey. It contains mainly $\mathrm{Fe}_{2} \mathrm{O}_{3}, \mathrm{Al}_{2} \mathrm{O}_{3}, \mathrm{SiO}_{2}, \mathrm{TiO}_{2}, \mathrm{Na}_{2} \mathrm{O}$, and $\mathrm{CaO}$. $\mathrm{RM}$ receiving from plant was filtered and dried at $105^{\circ} \mathrm{C}$. Dried red mud was donated as RM. Red mud was also activated to remove the acid soluble constituents according to literature (Pratt and Christoverson, 1982). Activation consisted of boiling the RM in aqueous $\mathrm{HCl}$ for $2 \mathrm{~h}$ and adding aqueous ammonia to $\mathrm{pH}$. The resulting precipitate was filtered, washed with distillated water, dried at $105{ }^{\circ} \mathrm{C}$ and calcined at $500{ }^{\circ} \mathrm{C}$ for $2 \mathrm{~h}$. Activated red mud was denoted as ARM. $10 \% \mathrm{Fe}_{2} \mathrm{O}_{3}-90 \% \mathrm{CeO}_{2}$ was prepared by

Table 1

Elemental composition and metal analysis of algal biomasses, wt\% (on dry basis).

\begin{tabular}{llll}
\hline & Fucus serratus & Laminaria digitata & Nannochloropsis oculata \\
\hline \multicolumn{2}{l}{ Elemental composition } & & \\
$\mathrm{C}$ & 36.5 & 33.5 & 22.9 \\
$\mathrm{H}$ & 4.8 & 4.4 & 4.2 \\
$\mathrm{~N}$ & 1.2 & 0.8 & 2.5 \\
$\mathrm{~S}$ & 0.5 & 0.7 & 1.0 \\
Ash content & & & \\
At $550^{\circ} \mathrm{C}$ & 21.4 & 26.5 & 57.0 \\
$\mathrm{At} 850^{\circ} \mathrm{C}$ & 14.8 & 14.9 & 13.9 \\
$\mathrm{Metal}$ analysis & & \\
$\mathrm{Si}$ & 0.1 & 0.1 & - \\
$\mathrm{Al}$ & - & - & 0.1 \\
$\mathrm{Fe}$ & - & - & 0.1 \\
$\mathrm{Ca}$ & 1.3 & 1.0 & 2.0 \\
$\mathrm{Mg}$ & 0.8 & 0.8 & 5.5 \\
$\mathrm{Na}$ & 3.5 & 3.8 & 18.0 \\
$\mathrm{~K}$ & 3.4 & 6.1 & 0.7 \\
\hline
\end{tabular}


coprecipitation method using ammonia as precipitating agent according to literature (Uddin et al., 2008). Starting material were iron nitrate $\left(\mathrm{Fe}\left(\mathrm{NO}_{3}\right)_{3}\right)$ and cerium nitrate $\left(\mathrm{Ce}\left(\mathrm{NO}_{3}\right)_{3}\right) .20 \mathrm{wt}$.\% of the iron salt or the mixture of the salts is added to a required amount (10\% in excess of the stoichiometric amount) of $7 \mathrm{wt} . \%$ ammonia water solution quickly and stirred vigorously. The precipitate was washed with deionized water. The precipitate was then filtered and dried at $110^{\circ} \mathrm{C}$ for $24 \mathrm{~h}$ and calcined at $700{ }^{\circ} \mathrm{C}$ in air for $1 \mathrm{~h}$. The calcined samples were crushed and sieved into average size of $0.367 \mathrm{~mm}$. Surface area and density of catalysts are given in Table 2. The metal contents of the RM and ARM were analysed by the X-ray fluorescence technique (Table 3).

The powder X-ray diffraction (XRD) patterns of ARM and RM catalysts were recorded using a Philips $\mathrm{X}^{\prime}$ Pert Pro diffractometer with a $\mathrm{Cu}$ KR irradiation ( $40 \mathrm{kV}, 45 \mathrm{~mA})$.

\subsection{Gasification experiments}

Gasification of biomass is carried out in a two stage (two fixedbed) quartz reactor. Fig. 1 shows scheme of steam gasification: biomass samples were placed in the first reactor bed and a catalyst sample was placed in the second bed. The experimental procedure involved the following steps: in a typical run, a very small amount of biomass sample $(0.04 \mathrm{~g}$, particle size: $0.15-0.30 \mathrm{~mm})$ was placed in the top section on a quartz wool bed and the desired amount $(0.065 \mathrm{ml})$ of catalyst was placed on the second quartz wool bed. The reactor system was purged with $\mathrm{N}_{2}$ flow for $30 \mathrm{~min}$, while a mixture of water vapour (generated in a bubbler at $70{ }^{\circ} \mathrm{C}$ ) and $\mathrm{N}_{2}$ with a composition of $30 \% \mathrm{H}_{2} \mathrm{O}-\mathrm{N}_{2}$ at flow rate of $20 \mathrm{~cm}^{3} \mathrm{STP} /$ min was passed through the reactor bypass. In the meantime, the bottom bed (catalyst bed) was heated to the predetermined temperature $\left(600-850{ }^{\circ} \mathrm{C}\right.$ ) at rate of $3^{\circ} \mathrm{C} / \mathrm{min}$ in $\mathrm{N}_{2}$ flow. When the bottom bed (catalyst bed) temperature reached the desired temperature, heating of the top bed (biomass bed) to the desired temperature was commenced at a heating rate of $3^{\circ} \mathrm{C} / \mathrm{min}$ and a mixture of $30 \% \mathrm{H}_{2} \mathrm{O}-\mathrm{N}_{2}$ was passed through the reactor. When the top bed (biomass bed) temperature reached $200^{\circ} \mathrm{C}$, analysis of the reactor outlet gas (product gas) was started with an online gas chromatograph during heating. Product gas was also collected in two sampling bags at different time intervals. The online GC analyses were performed during heating at different time intervals. The product gases are analysed with two online gas chromatographs equipped with a TCD and three columns: a Molecular Sieve 13 column was used to analyse $\mathrm{H}_{2}$ with Ar carrier and $\mathrm{O}_{2}$, $\mathrm{CO}$ and $\mathrm{CH}_{4}$ was analysed with He carrier; a Porapak QS column with He carrier was used to analyse $\mathrm{CO}_{2}, \mathrm{CH}_{4}$ and $\mathrm{C}_{2} \mathrm{H}_{4}$. This micro reactor system is very convenience for the evaluation the catalytic activity and gas yields. Due to the low amount of the biomass sample used in this study (about $0.04 \mathrm{~g}$ in each run of experiment), tar product

Table 2

Surface area and density of catalysts.

\begin{tabular}{lcl}
\hline & Surface area $\left(\mathrm{m}^{2} / \mathrm{g}\right)$ & Density $(\mathrm{g} / \mathrm{cc})$ \\
\hline $\mathrm{RM}$ & 15 & 0.7 \\
$\mathrm{ARM}$ & 158 & 0.7 \\
$\mathrm{Fe}_{2} \mathrm{O}_{3}-\mathrm{CeO}_{2}$ & 22 & 1.0 \\
\hline
\end{tabular}

Table 3

XRF results of ARM and RM, wt\%.

\begin{tabular}{lrlllllllll}
\hline & \multicolumn{1}{c}{$\mathrm{Na}$} & $\mathrm{Mg}$ & $\mathrm{Al}$ & $\mathrm{Si}$ & $\mathrm{P}$ & $\mathrm{S}$ & $\mathrm{K}$ & $\mathrm{Ca}$ & $\mathrm{Ti}$ & $\mathrm{Fe}$ \\
\hline ARM & 0.2 & 0.3 & 17.4 & 12.6 & - & 0.1 & 0.1 & 2.2 & 6.6 & 59.8 \\
RM & 12.7 & 0.5 & 14.5 & 12.0 & - & 0.2 & 0.5 & 3.8 & 5.9 & 49.5 \\
\hline
\end{tabular}

could not be analysed. Therefore, the activity of the catalysts and the gas yields were evaluated by using the data of the gaseous products only.

\section{Results and discussion}

\subsection{Gasification profile of algae}

In the heating regime and gasification system used in this study, the decomposition of algae in presence of steam proceeds in two steps: the first step (at $200-500{ }^{\circ} \mathrm{C}$ ) includes evolution and decomposition of volatile matters including tar; and the second step includes the steam gasification of char in the top bed at 500$800^{\circ} \mathrm{C}$. Following reaction pathways are possible (Moon et al., 2013):

Pyrolysis $\mathrm{C}_{x} \mathrm{H}_{y} \mathrm{O}_{z} \rightarrow \operatorname{tar}+$ permanent gases $\left(\mathrm{CO}, \mathrm{CO}_{2}, \mathrm{H}_{2}, \mathrm{CH}_{4}, \mathrm{C}_{2}^{+}\right)$ $+\mathrm{H}_{2} \mathrm{O}$

Steam-tar reforming $\mathrm{C}_{x} \mathrm{H}_{y}+2 x \mathrm{H}_{2} \mathrm{O}$

$$
\rightarrow(2 x+y / 2) \mathrm{H}_{2}+x \mathrm{CO}_{2}
$$

Char gasification $\mathrm{C}+\mathrm{H}_{2} \mathrm{O} \rightarrow \mathrm{CO}+\mathrm{H}_{2}$

Water-gas shift (WGS) $\mathrm{CO}+\mathrm{H}_{2} \mathrm{O} \rightarrow \mathrm{CO}_{2}+\mathrm{H}_{2}$

Steam-methane reforming $\mathrm{CH}_{4}+\mathrm{H}_{2} \mathrm{O} \rightarrow \mathrm{CO}+3 \mathrm{H}_{2}$

Boudouard $\mathrm{C}+\mathrm{CO}_{2} \rightarrow 2 \mathrm{CO}$

Methanation $\mathrm{C}+2 \mathrm{H}_{2} \mathrm{O} \rightarrow \mathrm{CH}_{4}$

In order to show the gasification profile of algae, distribution of main gaseous products obtained from steam gasification was investigated in the absence of catalyst. For this purpose, the top bed (biomass bed) was heated from room temperature to $850{ }^{\circ} \mathrm{C}$ (heating rate $3{ }^{\circ} \mathrm{C} / \mathrm{min}$ ) while the temperature of bottom bed was hold at $850^{\circ} \mathrm{C}$. Fig. 2 shows the distribution of main gaseous products evolved from steam gasification of algal biomass as a function of the top bed (biomass bed) temperature. The production rate of the gas products was calculated from the GC analysis of the gas flowing out of the reactor and recorded with the unit of $\mathrm{cc} / \mathrm{min}$. The results from thermal gasification of algae are given in Fig. 2. For each alga, there are two main peak areas appeared around $250{ }^{\circ} \mathrm{C}$ and $700{ }^{\circ} \mathrm{C}$, respectively.

Similar profiles of gas formation have also been reported for lignocellulosic biomasses (Uddin et al., 2008; Gusta et al., 2009). CO was the main gas product in the temperature range $200-500{ }^{\circ} \mathrm{C}$, with a peak of production at around $250{ }^{\circ} \mathrm{C}$. In second area, $\mathrm{H}_{2}$ was mostly produced. Amount of $\mathrm{CO}$ and $\mathrm{CH}_{4}$ is in a trace level at this stage. It can be seen that there is no significantly peaks for $\mathrm{CO}$ and $\mathrm{CH}_{4}$ above $500{ }^{\circ} \mathrm{C}$. The temperatures at which the maximum formation rate of hydrogen was observed were $650{ }^{\circ} \mathrm{C}$, $700{ }^{\circ} \mathrm{C}$ and $750{ }^{\circ} \mathrm{C}$ for $F S, L S$ and $N O$ respectively. As the gases over $500{ }^{\circ} \mathrm{C}$ are generated from the gasification of pyrolysis char (Eq. (2)), char characteristics are the main factor in the gas formation rates in thermal gasification. Although surface characteristic of chars formed during process could not be known, the differences among algal biomass may be attributed essentially to the amount and composition of the inorganic matter. On the other hand, the gas production rates were very low in the case of $N O$, comparing to seaweeds. Thermal steam gasification of FS has the highest gas production rate. On the other hand, a microalga has the lowest gas production rate. The reason might be the low carbon content of $N O$. 


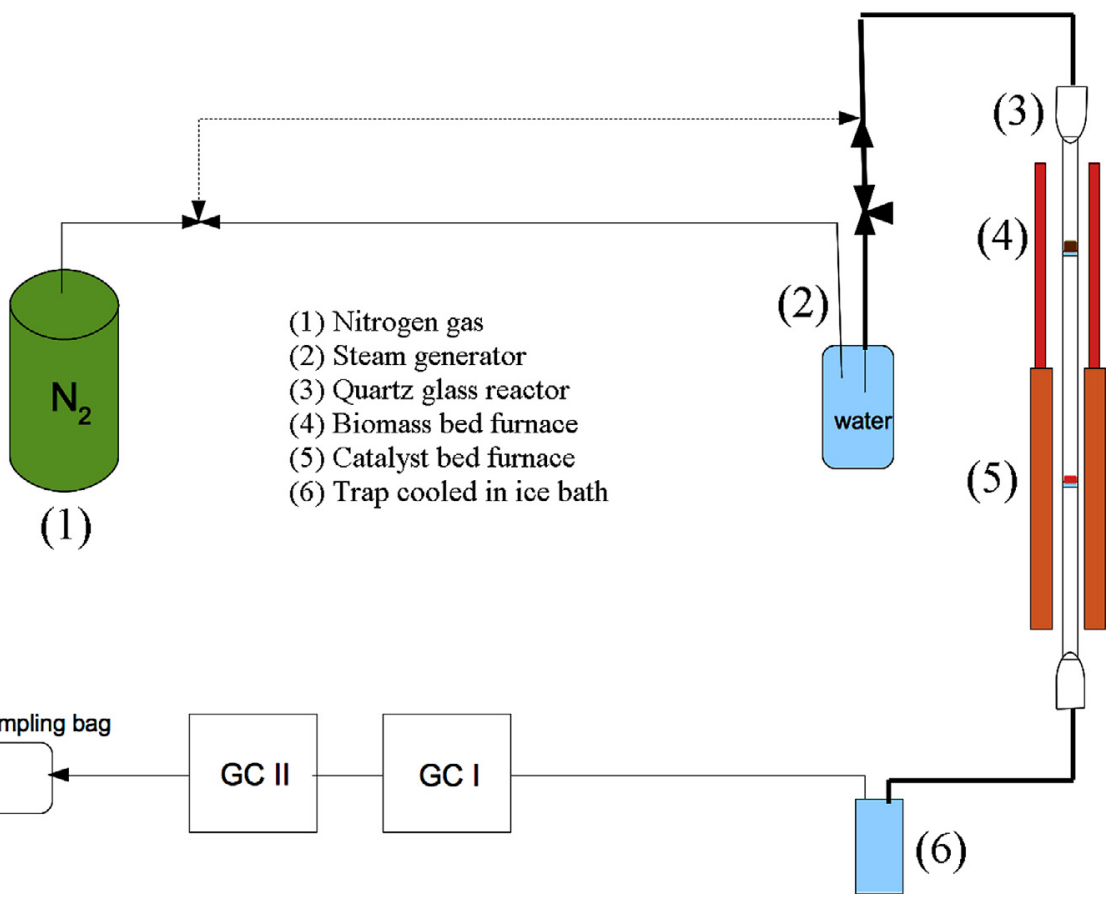

Fig. 1. Scheme of steam gasification.

\subsection{Gas yields from steam gasification of algae}

In this study, the product gases were analysed via both online gas chromatography every $15 \mathrm{~min}$ and off-line analysis at the end of the gasification. In off-line analysis by gas chromatography, product gas was collected in two Tedlar sampling bags, tar evolution $\left(200-500{ }^{\circ} \mathrm{C}\right)$ phase in one set of bags and char gasification $\left(500-850^{\circ} \mathrm{C}\right)$ phase in another set of bags. And gas yield was defined as the cumulative amount of gas produced per unit weight of algae on a dry mass basis. The final temperature of the top bed was maintained at $850{ }^{\circ} \mathrm{C}$ in all experiments. Catalytic gasification runs were designated as following the "Bottom bed (catalyst bed) temperature - Catalyst type", while thermal gasification runs were denoted as "Bottom bed (catalyst bed) temperature - $T$ ". For example, 700 ARM demonstrates the catalytic gasification experiment over ARM catalyst (Bottom bed temperature: $700^{\circ} \mathrm{C}$ ), whereas $700 \mathrm{~T}$ demonstrates the thermal gasification experiment (Bottom bed temperature: $700^{\circ} \mathrm{C}$ ). Figs. $3-5$ show the gas yields from the catalytic and non-catalytic gasification of algae. In the case of thermal steam gasification, the total yield of main gaseous products slightly increased with the increasing of bottom bed temperature from 700 to $850^{\circ} \mathrm{C}$. This indicates that higher temperature promotes thermal cracking and steam reforming of tar. The increase in thermal tar conversion by bottom bed temperature (Fig. 6) supports this conclusion.

The effect of catalyst on the gasification of algae was investigated by temperature programmed steam gasification in the top bed at $200-850{ }^{\circ} \mathrm{C}$ followed by the catalytic gasification of volatile matters including tar in the bottom bed at a constant temperature of $700{ }^{\circ} \mathrm{C}$. In catalytic gasification, bottom bed (catalyst bed) was held at $700{ }^{\circ} \mathrm{C}$ for clarification of the catalytic gasification at low temperature. In catalytic runs, the catalysts can affect the activity differently for 1, 3 and 4 reaction pathways depending on the types and performance of the catalysts, whereas pyrolysis and reaction pathways 2, 5 and 6 are independent of the catalyst.

A remarkable change in the cumulative production of gases, compared to the non-catalytic gasification at $700{ }^{\circ} \mathrm{C}$, was observed by using of catalysts.
For all algae, the use of $\mathrm{RM}$ and $\mathrm{Fe}_{2} \mathrm{O}_{3}-\mathrm{CeO}_{2}$ led to increase in the $\mathrm{H}_{2}$ and $\mathrm{CO}_{2}$ production and decrease in $\mathrm{CO}$. The reduction in the $\mathrm{CO}$ content is desirable when the hydrogen production is aimed. From these results, it is evident that the $\mathrm{CO}$ produced from the tar and char gasification was converted to $\mathrm{CO}_{2}$ and $\mathrm{H}_{2}$ by the WGS reaction (Eq. (3)) in the presence of catalyst. In contrast, $\mathrm{CO}$ increased or remained nearly constant in the case of ARM. This shows ARM had no considerable activity for the WGS reaction which led to $\mathrm{CO}$ consumption. The reason will be discussed later.

No significant influence of the catalysts was observed on $\mathrm{CH}_{4}$ production.

In the case of $F S, \mathrm{Fe}_{2} \mathrm{O}_{3}-\mathrm{CeO}_{2}$ catalyst produced a yield of $1036 \mathrm{cc}$ hydrogen/g biomass; whereas hydrogen yield was $721 \mathrm{cc} / \mathrm{g}$ biomass for RM and $661 \mathrm{cc} / \mathrm{g}$ biomass for ARM. Similarly, the highest amount hydrogen production (937 cc hydrogen/g biomass) was obtained over $\mathrm{Fe}_{2} \mathrm{O}_{3}-\mathrm{CeO}_{2}$ catalyst from steam gasification of $L D$. It is clearly seen that $\mathrm{Fe}_{2} \mathrm{O}_{3}-\mathrm{CeO}_{2}$ catalyst is a most effective catalyst for the water gas shift reaction. The hydrogen production activity of catalysts was in the order: $\mathrm{Fe}_{2} \mathrm{O}_{3}-\mathrm{CeO}_{2}>$ $\mathrm{RM}>$ ARM. Slightly lower $\mathrm{H}_{2}$ and $\mathrm{CO}_{2}$ yields were obtained in catalytic gasification of $L D$ than that of $F S$.

Although there was no significant effect on overall gas amount, the composition of the gases differed with using ARM and RM. The $\mathrm{H}_{2}$ and $\mathrm{CO}_{2}$ concentrations from RM were higher than ARM. The reason may be higher amount of alkali metal (Na) in RM. XRD patterns of RM and ARM (not presented here) showed that activation led to remove sodium aluminium silicate hydrate. The alkali metal carbonates was reported to increase the yields of permanent gases $\left(\mathrm{H}_{2}, \mathrm{CO}_{2}\right.$, etc.) by promoting the decomposition reactions of tar and light hydrocarbons (Xie et al., 2009). It seems that ARM mainly catalysed the syngas production reaction (Eq. (4)), but RM catalysed both the syngas production and WGS reaction.

Because of negligible difference in the gas yields from $L D$ and $F S$, it was concluded that the species of tested seaweeds did not have any influence on gas yields. This may be explained by the fact that their elemental and inorganic compositions were not much different from each other. 

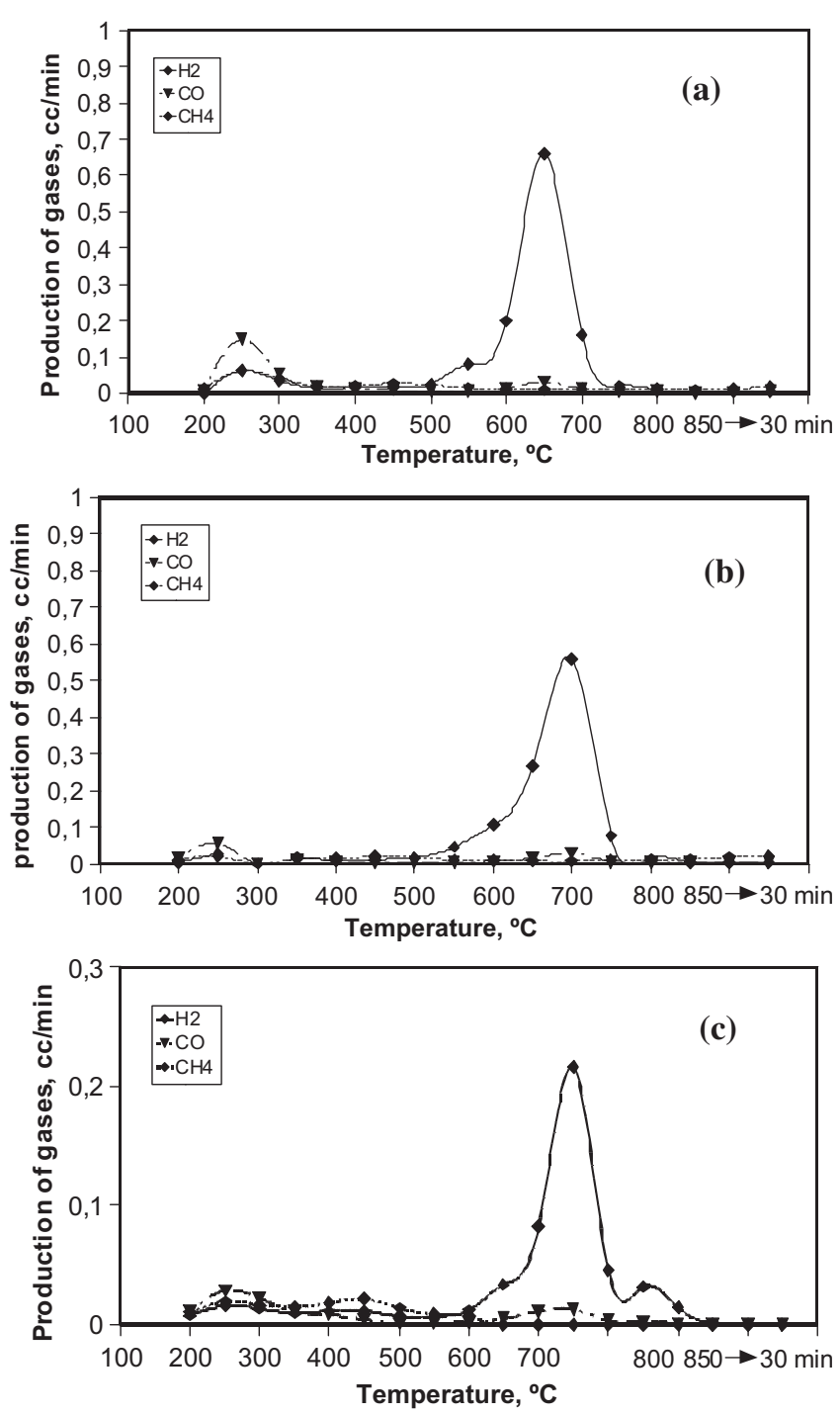

Fig. 2. Production rate of gases from thermal steam gasification of algae (a) FS, (b) $L D$ and (c) NO.

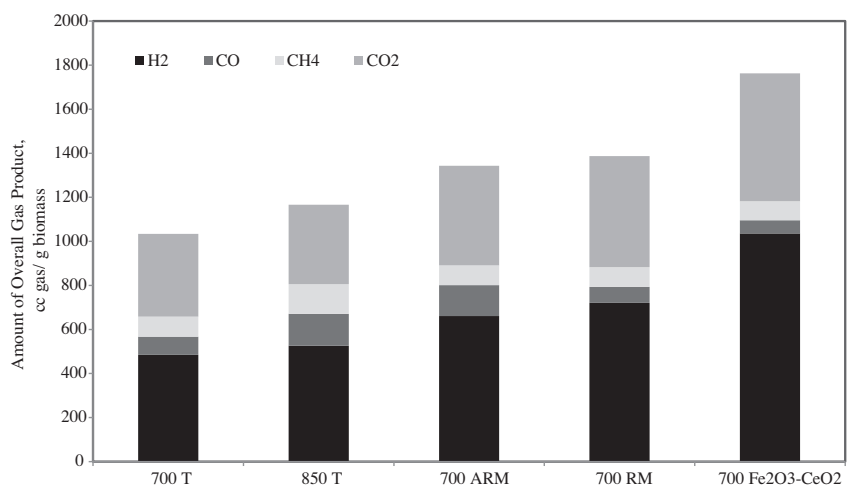

Fig. 3. Thermal and catalytic steam gasification of Fucus serratus.

Compared to seaweeds, microalga (NO) displayed the lowest gas yields, which was correlated to its higher ash content (Fig. 5). As in the case of seaweeds, $\mathrm{Fe}_{2} \mathrm{O}_{3}-\mathrm{CeO}_{2}$ catalyst showed the highest activity for $\mathrm{H}_{2}$ and $\mathrm{CO}_{2}$ production. $\mathrm{Fe}_{2} \mathrm{O}_{3}-\mathrm{CeO}_{2}$ catalyst produced about $413 \mathrm{cc} \mathrm{H}_{2} / \mathrm{g}$ biomass and $278 \mathrm{cc} \mathrm{CO}_{2} / \mathrm{g}$ biomass.

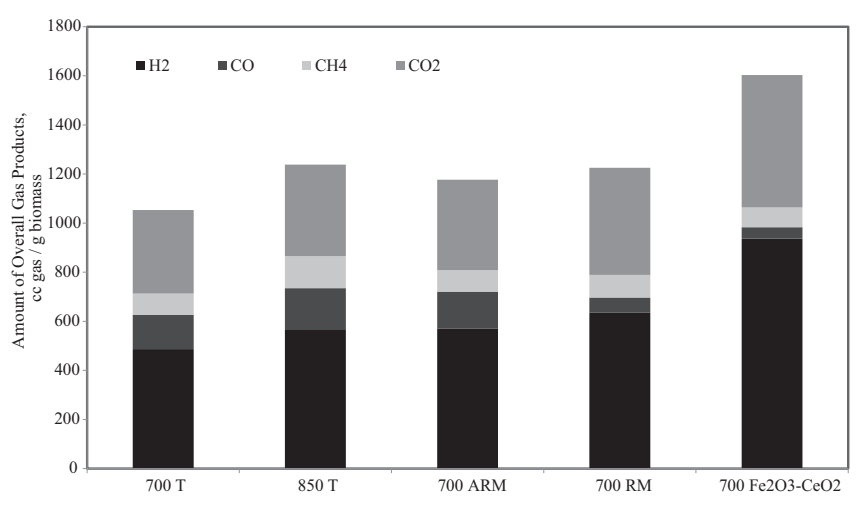

Fig. 4. Thermal and catalytic steam gasification of Laminaria digitata.

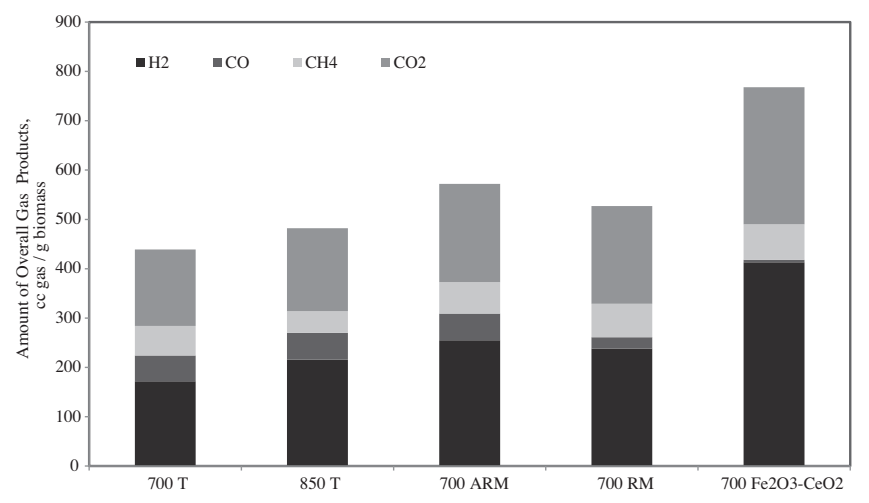

Fig. 5. Thermal and catalytic steam gasification of Nannochloropsis oculata.

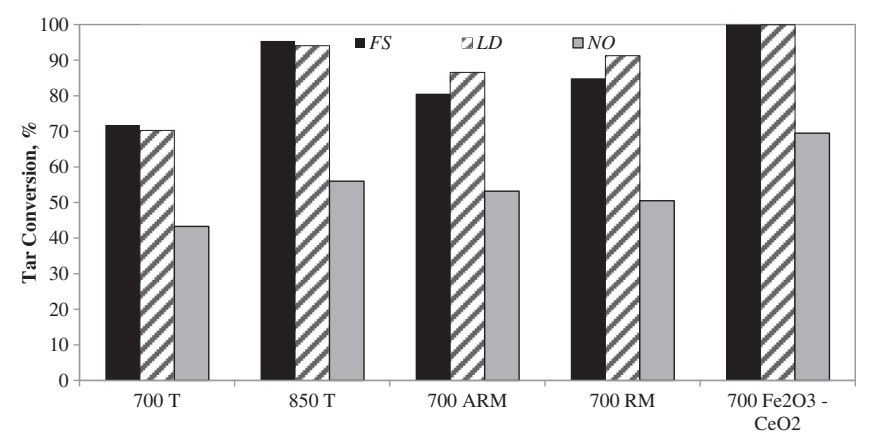

Fig. 6. Tar conversion of algae.

In a previous study (Schumacher et al., 2011) on hydrothermal gasification of macroalgae it was found that $7.5 \mathrm{mmol} \mathrm{H}_{2} / \mathrm{g}$ biomass and $6.6 \mathrm{mmol} \mathrm{H}_{2} / \mathrm{g}$ biomass were produced for $F S$ and $L D$, respectively. Higher yields of $\mathrm{H}_{2}$ found in this study showed that steam gasification may be more desirable than hydrothermal gasification. It should be noted that the hydrogen yields obtained from seaweeds in this study considerably higher than that reported for catalytic gasification of lignocellulosic biomasses in literature. In previous studies, hydrogen yields were found as approximately $5.0 \mathrm{~mol} / \mathrm{kg}$-biomass for pine sawdust (Hurley et al., 2012); approximately $650 \mathrm{cc} / \mathrm{g}$ biomass for cedar wood (Uddin et al., 2008); $24.6 \mathrm{mmol} / \mathrm{g}$ biomass (daf) for livestock manure compost (Xiao et al., 2010); $60 \mathrm{mmol} / \mathrm{g}$ biomass (daf) for red pine (Le et al., 2010), $1104 \mathrm{ml} / \mathrm{g}$ biomass (daf) for fowl manure (Zhang et al., 2011). A direct quantitative comparison between above data and 
our yields cannot be done because of differences in gasification conditions and process configurations. The results reveal that algal biomass is a potential feedstock for steam gasification. It should be noted that a successful application of algal biomass as feedstock for hydrogen production by the steam gasification will largely depend on the dewatering of algal biomass at cheaper cost. But, in a biorefinery approach which consists in the production of a wide range of biofuels and chemicals from algal biomass, steam gasification can be an economically beneficial and feasible process.

\subsection{Tar conversion}

As mentioned before, tar formation is the main problem of gasification processes. As it is well known, the composition and quantity of tar depend on mainly the biomass type and gasification conditions. Catalytic gasification can be considered as the best promising technique for tar elimination and several types of catalysts have been tested to decompose tar. One of the aims of this study is focussed on the tar conversion during gasification of algae. For this purpose, the catalytic tar conversion activities of three types of iron catalyst were tested.

In our experimental system, the decomposition of algae with steam proceeds in the following steps: pyrolysis of biomass and evolution of volatile matters including tars at $200-500{ }^{\circ} \mathrm{C}$; and steam gasification of char at $500-800^{\circ} \mathrm{C}$ in the top bed (biomass bed). Since it is not possible to collect tar product perfectly in the present micro reactor system, the results relating to tar decomposition were given on the basis of carbon amounts in gaseous products according to literature (Uddin et al., 2008). Thus; tar conversion is determined via the carbonaceous gas product emitted between 200 and $500{ }^{\circ} \mathrm{C}$ (biomass bed temperature). The product emitted during this phase is a mixture of gases $\left(\mathrm{CO}, \mathrm{CH}_{4}, \mathrm{CO}_{2}\right.$, and $\mathrm{C}_{2} \mathrm{H}_{4}$ ) and condensable organic compounds. On the other hand, the carbonaceous gas product emitted between $500-850{ }^{\circ} \mathrm{C}$ is derived from char gasification. Using gas analysis, the carbon amount (as mole) in gases from char gasification was calculated. Then the percent of carbon yield of char gasification was calculated by dividing carbon content of gases emitted from char gasification to carbon content in algae. By assuming, total carbon yield of steam gasification is $100 \%$, maximum carbon amount in volatiles emitted between 200 and $500{ }^{\circ} \mathrm{C}$ was calculated for thermal gasification runs.

By comparison of carbon amounts between thermal and catalytic runs, tar conversion can be found. If volatile matter (including tar) content of the algae is completely decomposed into gaseous products, tar decomposition should be $100 \%$.

The tar conversion is defined as;

\section{$\%$ Tar conversion}

$=\frac{\text { Carbon gases collected in catalytic run }\left(200-500^{\circ} \mathrm{C}\right)}{\text { Maximum amount of carbon emitted }\left(200-500^{\circ} \mathrm{C}\right)} \times 100$

The repeatability of the data (results) was accurate within $\pm 5 \%$ differences. Tar conversion results are given in Fig. 6. In the case of thermal gasification, noncatalytic tar conversion increased in the range of $29-34 \%$ by increasing catalyst bed temperature from 700 to $800{ }^{\circ} \mathrm{C}$. The increase of tar conversion was also reported by Gusta et al. (2009) for the gasification of woody biomass (Jack pine sawdust) with increasing catalyst bed temperature from 750 to $800{ }^{\circ} \mathrm{C}$. And they stated that, at $800^{\circ} \mathrm{C}$, coke deposits from thermal cracking of tar reacted with the steam on the quartz support material in catalyst bed. For each alga, the presence of a catalyst reduced the temperature for tar cracking and improved the tar conversion. $\mathrm{Fe}_{2} \mathrm{O}_{3}-\mathrm{CeO}_{2}$ was the most effective for tar decomposition.

For the seaweeds ( $F S$ and $L D$ ), on the $\mathrm{Fe}_{2} \mathrm{O}_{3}-\mathrm{CeO}_{2}$, the tar conversion was complete. Both ARM and RM also increased tar conversion comparing to tar conversion of thermal steam gasification at the same conditions. In the case of micro algae (NO), tar conversion was always below $70 \%$, even in presence of $\mathrm{Fe}_{2} \mathrm{O}_{3}-\mathrm{CeO}_{2}$. This might be due to the high content of sodium carbonate in micro algae. The big difference in ash content determined between at $550{ }^{\circ} \mathrm{C}$ and at $850{ }^{\circ} \mathrm{C}$ shows the existence of high amount carbonates. The sodium carbonate in micro algae might affect the composition of volatiles emitted between 200 and $500{ }^{\circ} \mathrm{C}$. The effect of alkali carbonates on the gasification was also observed a previous study related to steam gasification of biomass. It was demonstrated that the presence of catalyst increased the char yield during the volatilization stage but then decreased the char yield during the second stage of the gasification process (Sutton et al., 2001).

\section{Conclusion}

In steam gasification of algal biomass, the use of catalysts enhanced both tar degradation and hydrogen production via water-shift reaction. In catalytic gasification, tar removal efficiency varied from 80 to $100 \%$. The catalytic activity of catalysts was in the order $\mathrm{Fe}_{2} \mathrm{O}_{3}-\mathrm{CeO}_{2}>\mathrm{RM}>\mathrm{ARM}$ in terms of hydrogen production. The $\mathrm{H}_{2}$ yield of seaweeds was higher than that of microalgae. Different amounts of inorganics between seaweeds and micro algae resulted in the different gas yields. The results obtained in this study could indicate that steam gasification of algae for hydrogen production is promising.

\section{Acknowledgements}

We would like to acknowledge FP7 Marie-Curie IAPP-Project No: 230598 for providing algae which are investigated in that project and financially supporting Prof. Dr. Jale Yanik. We also thank to Prof. Dr. Yoshiei Kato for his collaboration and invitation to Environmental Analytical Chemistry Laboratory, Okayama University.

\section{References}

Anisa, S., Zainala, Z.A., 2011. Tar reduction in biomass producer gas via mechanical, catalytic and thermal methods: a review. Renew. Sust. Energy Rev. 15, 23552377.

Ferreira, A.F., Ribeiro, L., Batista, A.P., Marques, P.S.S., Nobre, B.P., Palavra, A.M.F., da Silva, P.P., Gouveia, L., Silva, C., 2013. A biorefinery from Nannochloropsis sp. microalga - energy and $\mathrm{CO}_{2}$ emission and economic analyses. Bioresour. Technol. 138, 235-244.

Florin, N.H., Harris, A.T., 2008. Enhanced hydrogen production from biomass with in situ carbon dioxide capture using calcium oxide sorbents. Chem. Eng. Sci. 63, 287-316.

Garcia, L., Salvador, M.L., Arauzo, J., Bilbao, R., 2001. $\mathrm{CO}_{2}$ as a gasifying agent for gas production from pine sawdust at low temperatures using a $\mathrm{Ni}-\mathrm{Al}$ coprecipitated catalyst. Fuel Process. Technol. 69, 157-174.

Gil, J., Corella, J., Aznar, M.P., Caballero, M.A., 1999. Biomass gasification in atmospheric and bubbling fluidized bed: effect of the type of gasifying agent on the product distribution. Biomass Bioenergy 17, 389-403.

Güell, B.M., Babich, I., Nicholas, K.P., Gardeniers, J.G.E., Lefferts, L., Seshan, K., 2009. Design of a stable steam reforming catalyst - a promising route to sustainable hydrogen from biomass oxygenates. Appl. Catal. B 90, 38-44.

Güell, B.M., van Rossum, G., van Swaaij, W.P.M., Kersten, S.R.A., Lefferts, L., Seshan, K., 2011. Challenges in the production of sustainable fuels from pyrolysis oil design of efficient catalysts for gasification of char. Appl. Catal. B 10, 587-597.

Gusta, E., Dalai, A.K., Uddin, Md.A., Sasaoka, E., 2009. Catalytic decomposition of biomass tars with dolomites. Energy Fuels 23, 2264-2272.

Hanaoka, T., Inoue, S., Uno, S., Ogi, T., Minowa, T., 2005. Effect of woody biomass components on air-steam gasification. Biomass Bioenergy 28, 69-76.

Hu, G., Xu, S., Li, S., Xiao, C., Liu, S., 2006. Steam gasification of apricot stones with olivine and dolomite as downstream catalysts. Fuel Process. Technol. 87, 375382.

Hurley, S., Xu, C., Preto, F., Shao, Y., Li, H., Wang, J., Tourigny, G., 2012. Catalytic gasification of woody biomass in an air-blown fluidized-bed reactor using Canadian limonite iron ore as the bed material. Fuel 91, 170-176.

Kaewpanha, M., Guan, G., Hao, X., Wang, Z., Kasai, Y., Kusakabe, K., Abudula, A., 2014. Steam co-gasification of brown seaweed and land-based biomass. Fuel Process. Technol. 120, 106-112. 
Khelfa, A., Sharypov, V., Finqueneisel, G., Weber, J.V., 2009. Catalytic pyrolysis and gasification of Miscanthus Giganteus: haematite $\left(\mathrm{Fe}_{2} \mathrm{O}_{3}\right)$ a versatile catalyst. J. Anal. Appl. Pyrolysis 84, 84-88.

Kimura, T., Miyazawa, T., Nishikawa, J., Kado, S., Okumura, K., Miyao, T., 2006. Development of Ni catalysts for tar removal by steam gasification of biomass. Appl. Catal. B. 68, 160-170.

Le, D.D., Xiao, X., Morishita, K., Li, L., Takarada, T., 2010. Development of a Ni-loaded brown coal char catalyst for fluidized bed biomass gasification at low reaction temperatures. J. Chem. Eng. Jpn. 43, 443-450.

Liu, H., Chen, T., Zhang, X., Li, J., Chang, D., Song, L., 2010. Effect of additives on catalytic cracking of biomass gasification tar over a nickel-based catalyst. Chin. J. Catal. 31, 409-414.

Marcilla, A., Catalá, L., García-Quesada, J.C., Valdés, F.J., Hernández, M.R., 2013. A review of thermochemical conversion of microalgae. Renew. Sust. Energy Rev. 27, 11-19.

Mermoud, F., Salvador, S., Van de Steene, L., Golfier, F., 2006. Influence of the pyrolysis heating rate on the steam gasification rate of large wood char particles. Fuel 85, 1473-1482.

Min, Z., Asadullah, M., Yimsiri, P., Zhang, S., Wu, H., Li, C., 2011. Catalytic reforming of tar during gasification. Part I. Steam reforming of biomass tar using ilmenite as a catalyst. Fuel $90,1847-1854$.

Miyazawa, T., Kimura, T., Nishikawa, J., Kado, S., Kunimori, K., Tomishige, K., 2006 Catalytic performance of supported Ni catalysts in partial oxidation and steam reforming of tar derived from the pyrolysis of wood biomass. Catal. Today 115 , 254-562.

Moon, J., Lee, J., Lee, U., Hwang, J., 2013. Transient behavior of devolatilization and char reaction during steam gasification of biomass. Bioresour. Technol. 133, 429-436.

Pratt, K.C., Christoverson, V., 1982. Hydrogenation of a model hydrogen donor system using activated red mud catalyst. Fuel 61, 460-462.

Ross, A.B., Jones, J.M., Kubacki, M.L., Bridgeman, T., 2008. Classification of macro algae as fuel and its thermochemical behaviour. Bioresour. Technol. 99, 496504.

Ruiz, H., Rodríguez-Jasso, R.M., Fernandes, B.D., Vicente, A., Teixeira, J., 2013. Hydrothermal processing, as an alternative for upgrading agriculture residues and marine biomass according to the biorefinery concept: a review. Renew. Sustain. Energy Rev. 21, 35-51.

Sanchez-Silva, L., López-González, D., Garcia-Minguillan, A.M., Valverde, J.L., 2013. Pyrolysis, combustion and gasification characteristics of Nannochloropsis gaditana microalgae. Bioresour. Technol. 130, 321-331.

Schumacher, M., Yanık, J., Sınağ, A., Kruse, A., 2011. Hydrothermal conversion of seaweeds in a batch autoclave. J. Supercrit. Fluids 58, 131-135.

Singh, A., Olsen, S.I., 2011. A critical review of biochemical conversion, sustainability and life cycle assessment of algal biofuels. Appl. Energy 88, 3548-3555.

Sutton, D., Kelleher, B., Ross, J.R.H., 2001. Review of literature on catalysts for biomass gasification. Fuel Process. Technol. 73, 155-173.

Tang, L., Yamaguchi, D., Burke, N., Trimm, D., Chiang, K., 2010. Methane decomposition over ceria modified iron catalysts. Catal. Commun. 11, 1215 1219.

Uddin, Md.A., Tsuda, H., Wu, S., Sasaoka, E., 2008. Catalytic decomposition of biomass tars with iron oxide catalysts. Fuel 87, 451-459.

Wi, S.G., Kim, H.J., Mahadevan, S.A., Yang, D.J., Bae, H.J., 2009. The potential value of the seaweed Ceylonmoss (Gelidium amansii) as an alternative bioenergy source. Bioresour. Technol. 100, 6658-6660.

Xiao, X., Le, D.D., Li, L., Meng, X., Cao, J., Morishita, K., Takarada, T., 2010. Catalytic steam gasification of biomass in fluidized bed at low temperature: conversion from livestock manure compost to hydrogen-rich syngas. Biomass Bioenergy 34, 1505-1512.

Xie, Y.R., Shen, L.H., Xiao, J., Xie, D.X., Zhu, J., 2009. Influences of additives on steam gasification of biomass. 1. Pyrolysis procedure. Energy Fuels 23, 5199-5205.

Xiwei, X., Enchen, J., Wang, M., Bosong, L., 2012. Rich hydrogen production from crude gas secondary catalytic cracking over $\mathrm{Fe} / \gamma-\mathrm{Al}_{2} \mathrm{O}_{3}$. Renew. Energy 39, 126 131.

Yanik, J., Stahl, R., Troeger, N., Sinag, A., 2013. Pyrolysis of algal biomass. J. Anal Appl. Pyrolysis 103, 134-141.

Yeh, T.M., Dickinson, J.G., Franck, A., Linic, S., Thompson Jr, L.T., Savage, P.E., 2013 Hydrothermal catalytic production and chemicals from aquatic biomass. J. Chem. Technol. Biotechnol. 88, 13-24.

Zhang, S.Y., Wang, J., Cao, J.P., Takarada, T., 2011. $\mathrm{H}_{2}$ production from fowl manure by low temperature catalytic gasification. Bioresour. Technol. 102, 7561-7566. 